\title{
Some exercises with SIPRI's military expenditure alpha $(\alpha)$ data: Same story for Greece and Turkey?
}

\section{Gulay Gunluk-Senesen}

Gulay Gunluk-Senesen is Professor of Public Finance, Faculty of Political Sciences, Istanbul University, Istanbul, Turkey. She may be reached at gulaygs@istanbul.edu.tr.

\section{Abstract}

The purpose of this article is to assess the Stockholm International Peace Research Institute's (SIPRI) updated military expenditure data for Greece and Turkey. Testing for data reliability involves two stages. First, for 1949-2014, the time pattern of Turkish military expenditure is explored by comparing national military budget data with the updated SIPRI data. Second, the new data for 1980-2001 are used to replicate an earlier study on possible action-reaction military spending behavior between Greece and Turkey. The findings still hold when the analysis is based on SIPRI's updated data.

$\mathrm{T}$ he motivation for this article stems from the availability of an extended military expenditure data series with improved quality from the Stockholm International Peace Research Institute (SIPRI). In regard to Turkey, the first purpose of this article is to compare SIRPI's new data series to Turkish national data sources. Second, the new data are then employed to replicate aspects of an earlier study. This involves, in particular, a reestimation of possible action-reaction military spending behavior between Greece and Turkey, 1980-2001. The exercises presented in this article are based on SIPRI's alpha (SIPRI- $\alpha$ ) data made available to a select cohort of researchers in 2015 . $^{1}$

Comparing Turkish national budget data with SIPRI- $\alpha$ data For Turkey, publicly available national military spending data include the budgets of the Ministry of Defense, the Gendarmerie, and the Coast Guard. Until Turkey adopted the functional government budget classification (COFOG) of the EU in 2006, data for the latter two were lumped in with those for the Ministry of Defense. This traditional set of expenditure data for Turkish military institutions is available as from 1924 onward. SIPRI's military expenditure data come in a broader context and, for any country, are higher than national data due to the inclusion of additional military-related activities, thus widening coverage beyond national military budget data. SIPRI's main source is NATO's dataset, constructed from reports by member country governments. Military-related data except for the budgets of the Defense Ministry, Gendarmerie, and Coast Guard is undisclosed information and, until 2006, Turkish budget classifications did not even allow for partly cross-checking SIPRI (or NATO) figures. Recent improvements in data quality notwithstanding, approximating SIPRI (or
NATO) figures from Turkish national numbers still is a demanding issue. ${ }^{2}$

Figure 1 (on the next page) shows the ratio of SIPRI- $\alpha$ data to Turkish national military budget data for 1949 to 2014 . The ratio is almost always greater than 1 . Until 1974, this was on the order of 10 to 20 percent larger; thereafter on the order of 30 to 50 percent. Quite apart from issues related to the more inclusive nature of SIPRI's data — e.g., the magnitude of certain SIPRI components (pensions, procurement, other off-budget items added to the military budget) may have changeddiscrepancies between the Turkish military budget data (Ministry of Defense, the Gendarmerie, and the Coast Guard) and the SIPRI data could be due to a number of other issues. Thus, the SIPRI- $\alpha$ coverage (degree of inclusion) might have been revised or reorganizations in the Turkish military and paramilitary structure might have led to related financing mechanisms beyond the military budget. The simple ratio presentation of the two series in Figure 1 provides some insight into the potential information gain afforded by SIPRI's coverage as well as into peculiarities of Turkish military spending.

In Figure 1, the data points for 1949, 1955, and 1958 are unusual in that SIPRI- $\alpha$ military expenditure data for Turkey are either equal to or below the national data. Starting in 1974, the Cyprus conflict between Greece and Turkey certainly triggered extra Turkish military spending as well as ambiguities in spending items and the estimation of their size for 1975-1979. Turkish military rule from 1980-1983 and the economic crisis of 1979-1981 could also help to account for the observed data fluctuations. From the mid-1980s onward, the margin by which the SIPRI- $\alpha$ data exceed the Turkish national data fluctuates less and a declining trend is noticeable: 


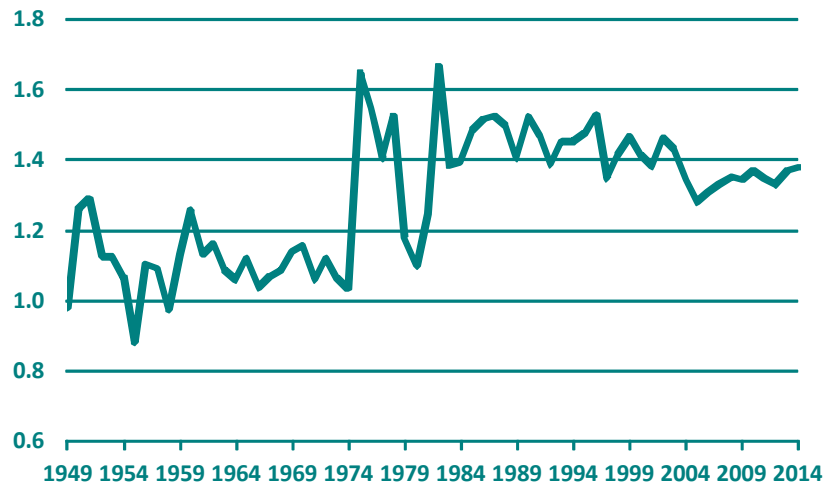

Figure 1: Ratio of SIPRI- $\alpha$ to Turkish national military budget data (both in current TRY). Sources: See endnote 2.

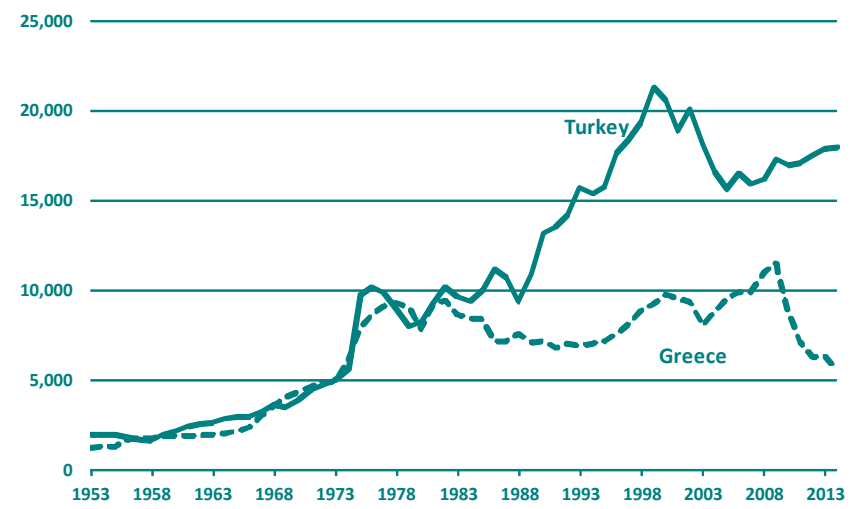

Figure 2: SIPRI- $\alpha$ military expenditure for Greece and Turkey, 1953-2014 (measured in constant USD2011). Source: www.sipri.org/databases/milex.

The SIPRI- $\alpha$ data suggest a ratio of generally greater than 1.4 until 2003, and less than 1.4 thereafter. $^{3}$

The figure prompts two questions. First, does the method used to construct SIPRI's $\alpha$-series differ for the pre-1974 and post-1981 periods? To my knowledge, there exists no explicit SIPRI-specific revision, so going through the underlying NATO dataset might provide answers but this falls outside the scope of this article. The second question is whether Turkish military expenditure beyond the traditional institutional budgets - defense, gendarmerie, and Coast Guard - increased over the past three decades. With reservations, the question is answered in the affirmative since this period coincides with Turkey's ambitious arms industry modernization program, initiated in 1985 and financed by the off-budget Defense Industry Support Fund (DISF). However, attributing the data discrepancy solely to DISF would not be justified without a detailed analysis of the component breakdown of related SIPRI$\alpha$ data, which also is beyond the scope of this article. ${ }^{4}$
Greece and Turkey: Military expenditure over six decades Turn now to the second purpose of the article, a comparison of the military expenditure of Greece and Turkey. Even though both countries joined NATO in 1952, the pair became a popular dyad in conflict studies as bilateral relations between Greece and Turkey oscillated between tension and détente until the year 2000. A large arms race-related literature accumulated, which resorted extensively to SIPRI as a major data source. Overall, the literature's findings are inconsistent, causality remains undetermined, and the issue of whether or not an arms race existed has not been resolved. Since 2000s both countries' threat perceptions of each other have changed, in part due to changes in political and economic factors both in the national and international domains, and an era characterized by rapprochement and even cooperation emerged. ${ }^{5}$

Capturing these oscillations, Figure 2 shows Greek and Turkish military expenditure measured in constant USD2011 prices. Despite the scale differences in population and economic heft between the two countries, simple visual inspection favors the arms race argument to hold for the three decades between 1953 and 1982. Over the past three decades, however, a different relationship structure appears to prevail. A military expenditure gap opened and then widened rapidly due to increases in Turkish military spending relative to the comparatively "stagnant" military spending of Greece. Nevertheless, the simple correlation coefficient for the whole period between these two data series is quite high $(r=0.81)$ and statistically significantly different from zero. Note that this coefficient is valid for linear relationships only. It does not imply causality but does imply movement in generally similar directions.

The validity of SIPRI's data is widely accepted, almost without criticism. Following the principle of "first validity, then reliability," the availability of the SIPRI- $\alpha$ data thus presents an opportunity to test its reliability. In this vein, the following replicates a previous study regarding Greek-Turkish bilateral relations.

Greek and Turkish relative military expenditure positions, 1979-2001

Reliability in scientific research refers to consistency of measurement. The new SIPRI- $\alpha$ data provide an opportunity to challenge, or affirm, research based on the "old" SIPRI data. Thus, an analysis by Gunluk-Senesen (2004) used SIPRI's military expenditure data for Greece and Turkey (in constant USD1990). The data was assembled by Christos Kollias and shared with Gunluk-Senesen, so I refer to this dataset here as CK\$1990. It covers the 1979-2001 period. The specific research question is whether the findings of the 2004 paper still 


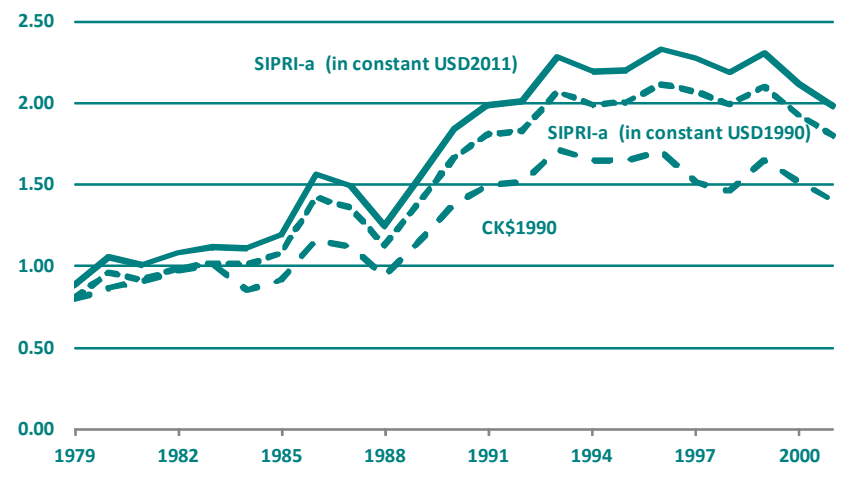

Figure 3: Ratios of Turkish to Greek military expenditure, alternative series (1979-2001). Sources: SIPRI- $\alpha$ at www.sipri.org/databases/milex; CK\$1990 in Kollias (2004) and Kollias and Paleologou (2002).

hold when employing the SIPRI- $\alpha$ data. The first order of business is to plot the relevant data. Thus, Figure 3 shows the ratio of Turkish to Greek military expenditure in CK\$1990 data (the bottom line) along with the SIPRI- $\alpha$ data for base year 2011 (the top line). It is a simple matter to rebase the SIPRI- $\alpha$ data to 1990 , thus eliminating the base year difference (the middle line).

Visually, the overall match between the CK\$1990 and the SIPRI- $\alpha \$ 1990$ series is quite close ${ }^{6}$ However, there are some peculiarities. In the CK\$1990 series, Greek military spending is above Turkey's - the ratio is less than one-for 1979-1982, 1984, 1985, and 1988. Then Turkey's spending overtakes Greece's by a significant margin as from 1989 onward. In contrast, the SIPRI- $\alpha$ \$1990 data show that Greek spending exceeded Turkey's only through 1982 and held essentially at parity in the mid-1980s. This likely is to due data revisions for Greece and could suggest a different interpretation of the countries' bilateral relations. Another peculiarity is that the SIPRI- $\alpha$ \$2011 series results in higher ratios than the SIPRI- $\alpha$ $\$ 1990$ series. For example, take the year 1993: The MilExTR/MilExGR ratios are 2.3, 2.1, and 1.7 for the SIPRI- $\alpha$ \$2011, SIPRI- $\alpha$ \$1990, and the CK\$1990 data, respectively. This again could imply changes in interpretations that are based on the CK\$1990 data.

Likely revisions, especially for Greece, are obvious from the summary data in Table 1 which shows the simple correlation coefficient $(r)$ and the Pearson rank correlation $(\rho)$ values for the ratios, absolute levels, and percentage changes of military expenditure among the different series. Correlations for the ratios depicted in Figure 3 are very close to unity. The series move in the same directions. Correlations for percentage changes in military expenditure are similar and relatively high for Greece and Turkey. However, both simple and rank
Table 1: Correlation coefficients I (1979-2001)

$\begin{array}{lr}\text { Correlation coefficients } & \begin{array}{l}\text { Data series: } \\ \alpha \$ 2011 \text { (or } \$ 19 \\ \text { Simple } r \text { for milexTR/milexGR }\end{array} \\ \text { and CK\$1990 } & 0.98 \\ \text { Rank } \rho \text { for milex } & \text { Turkey: } 0.99 \\ & \text { Greece: } 0.65 \\ \text { Simple } r \text { for milex } & \text { Turkey: } 0.99 \\ & \text { Greece: } 0.62 \\ \begin{array}{l}\text { Simple } r \text { for percent change in } \\ \text { milex, } 1980-2001\end{array} & \text { Turkey: } 0.89 \\ & \text { Greece: } 0.85\end{array}$

Note: All coefficients are statistically significantly different from zero at the 0.01 level.

Table 2: Correlation coefficients II (1979-2001)

$\begin{array}{lcccc}\text { Indicator } & \text { Stat. } & \text { CK\$1990 } & \begin{array}{l}\text { SIPRI- } \alpha \\ \$ 2011\end{array} & \begin{array}{l}\text { SIPRI- } \alpha \\ \$ 1990\end{array} \\ \text { Milex } & r & 0.70^{*} & 0.24 & 0.17 \\ \text { 1979-2001 } & \rho & 0.56^{*} & 0.08 & 0.08 \\ & & & & \\ \text { Percent } & & & & \\ \text { change in } & r & 0.11 & 0.04 & 0.04 \\ \text { milex, } & \rho & -0.07 & 0.04 & 0.04 \\ \text { 1980-2001 } & & & & \\ & \\ \text { Note: } * \text { 0.01 level. The CK } \$ 1990 \text { column is repeated from } \\ \text { Gunluk-Senesen (2004). }\end{array}$

correlations for Greece are much lower while those for Turkey are almost unity. The implication again is that the data for Greece are revised in the SIPRI- $\alpha$ data set. Hence previous findings based on CK $\$ 1990$ data, both in our specific case and in the literature more generally, may need to be reconsidered.

Retesting the action-reaction hypothesis: Different stories with different data?

I now turn to exploring whether these likely corrections for the Greek data cast a shadow on the hypothesis tests in Gunluk-Senesen (2004), which were based on the CK\$1990 data, regarding the action-reaction military expenditure behavior of the Greek-Turkish dyad. Simple reasoning suggests that threat perceptions within the dyad will be reflected in their concurrent military expenditure, arms imports, and military equipment spending, or possibly with a time lag. I elaborate 
bilateral responses here only for military expenditure in accordance with the available SIPRI- $\alpha$ data. Recognition of long-term considerations for military capacity building notwithstanding, analyses with lagged responses in Gunluk-Senesen (2004) are not repeated here due to space and scope considerations. I emphasize that focusing on quantitative aspects involves contesting inferences from the statistical tests conducted with different data sets. There certainly will be some variations in the values of the test statistics due to different units of measurement (that is, base years) but this is not the main issue at hand here.

Table 2 lists the correlations of the CK\$1990 series with the new SIPRI- $\alpha$ series (either base year 1990 or base year 2011). Both the simple and rank correlations between the military expenditure series of Greece and Turkey are statistically significant with the CK\$1990 data, implying a concurrent response to variations in threat perceptions as observed in Gunluk-Senesen (2004). Running the correlations with the SIPRI- $\alpha$ data, however, one comes to a different conclusion: The coefficient values now are low and statistically insignificant (revision of the data for Greece might be the underlying reason here again). The correlation coefficients for the percentage changes in the military expenditure series are insignificant with all three data series, casting doubt on the presence of any mutual concurrent responses.

The final exercise in this article regarding action-reaction behaviors takes into account the nature of Greek-Turkish bilateral relations, 1980-2001. As Gunluk-Senesen (2004) showed, relations improved in 11 years (1982, 1988-1992, 1995, and 1998-2001) and deteriorated, with different intensities, in the other 11 years (1980-1981, 1983-1987, 1993-1994 and 1996-1997). ${ }^{7}$ Splitting the 22 years of data into the two subsets of "harmony" and "conflict," respectively, the following null hypothesis is tested: There is no difference between the military expenditure (in levels and percentage changes) of Greece (Turkey) in more relaxed relative to more tense times with Turkey (Greece). Both nonparametric and parametric test results for central locations and dispersion are shown in Table 3 for Greece and in Table 4 for Turkey. ${ }^{8}$

In Table 4, when using the SIPRI- $\alpha$ \$2011 data, neither Turkey's level of nor percentage change in military expenditure in years of relative harmony with Greece are statistically different from more conflictual years. This finding is consistent with the inference drawn in Gunluk-Senesen (2004) which used the CK\$1990 data. Only the variance test results for Greece differs (in Table 3), an outcome which once more might be attributed to SIPRI- $\alpha$ data revision for Greece. The variance is greater in conflict years. Nevertheless, the findings based on the SIPRI- $\alpha$ data do not support the hypothesis of an arms (military
Table 3: Greek reaction to bilateral relations with Turkey, 1980-2001 (significance levels; p-values)

\begin{tabular}{lcccc} 
& CK\$1990 data & \multicolumn{2}{c}{ SIPRI- $\alpha \$ 2011$ data } \\
Test & Milex & $\begin{array}{c}\text { Percent } \\
\text { change } \\
\text { milex }\end{array}$ & Milex & $\begin{array}{c}\text { Percent } \\
\text { change } \\
\text { milex }\end{array}$ \\
$\begin{array}{l}\text { Mann- } \\
\text { Whitney U }\end{array}$ & 0.13 & 0.56 & 0.62 & 0.34 \\
Means & 0.06 & 0.84 & 0.25 & 0.38 \\
Variance & 0.003 & 0.06 & 0.09 & 0.02
\end{tabular}

Notes: The CK $\$ 1990$ series is taken from Gunluk-Senesen (2004). Findings using SIPRI- $\alpha$ \$2011 are essentially equal to those using SIPRI- $\alpha \$ 1990$.

Table 4: Turkish reaction to bilateral relations with Greece, 1980-2001 (significance levels; p-values)

\begin{tabular}{|c|c|c|c|c|}
\hline & \multicolumn{2}{|c|}{$C K \$ 1990$ data } & \multicolumn{2}{|c|}{ SIPRI- $\alpha \$ 2011$ data } \\
\hline Test & Milex & $\begin{array}{l}\text { Percent } \\
\text { change } \\
\text { milex }\end{array}$ & Milex & $\begin{array}{l}\text { Percent } \\
\text { change } \\
\text { milex }\end{array}$ \\
\hline $\begin{array}{l}\text { Mann- } \\
\text { Whitney U }\end{array}$ & 0.08 & 0.70 & 0.07 & 0.87 \\
\hline Means & 0.08 & 0.76 & 0.11 & 0.97 \\
\hline Variance & 0.99 & 0.93 & 0.33 & 0.17 \\
\hline
\end{tabular}

expenditure) race between Greece and Turkey.

\section{Conclusion}

Until the year 2000, tension, negotiation, and rapprochement oscillated in Greek-Turkish relations, a once popular research dyad among scholars of political science, international relations, and political economy. A good portion of the vast arms race literature focused on this dyad. (The Cyprus conflict, which peaked in 1974, has remained as a source of conflict.) However, a rich variety of econometric models have not resulted in coherent empirical findings, leaving the arms race issue inconclusive. For both countries, a complex set of other factors - e.g., nonbilateral economic and internal and external political factors - emerged as more determinative for military expenditure in general and arms spending in particular. That 
said, empirical work meant to contribute to attempts to generalize from case-specific findings is conditioned on the availability and quality of the underlying data. In this regard, SIPRI data have long been a common source for empirical research. Thus, the extended and updated SIPRI- $\alpha$ military expenditure data series offers opportunities for improved empirical research. This can, however, challenge earlier findings and the accumulated knowledge in the field.

With this background in mind, this article first cross-checked SIPRI's data with the national military budget data for Turkey and then employed the new data to retest an action-reaction hypothesis first published in Gunluk-Senesen (2004). That study failed to find evidence for an action-reaction pattern, a finding confirmed in the current article.

Since data is the main focus in this article, two issues are worth noting for future research on military expenditure: First, a comparison of the new SIPRI- $\alpha$ data and the national military budget data for Turkey suggests that cross-checks with national data generally could be quite useful not merely to show up limitations of national data but, more importantly, to query the extent of transparency in national data. This information is crucial for research in peace and security economics. This point may also be relevant for work on international comparisons which use, or will use, the SIPRI- $\alpha$ dataset. SIPRI has been providing internationally comparable and standardized data. For many years now, it has been the most reliable and most resorted to data source among researchers but an exploratory understanding of its coverage and structure at national levels would further improve our knowledge of the political and economic processes that generate these data. That said, if SIPRI made available a country-by-country breakdown of the components of military expenditure (e.g., personnel versus nonpersonnel spending), our understanding not only of SIPRI's methods but of patterns of resource allocation for military purposes would surely be improved. This would also serve to reinforce the validity of related SIPRI datasets.

Second, and more germane to the specific analyses carried out in this article, I note that the military expenditure data for Greece in the SIPRI- $\alpha$ dataset was revised for one or more years for the 1979-2001 sample. This suggests that comparative analyses for other countries and longer time spans should crosscheck earlier research findings as well, both a challenge and an opportunity to improve our work. Appreciating that these and other issues can be addressed with SIPRI's policy of open data access, I expect to see future comparative research notes similar to the present article.

\section{Notes}

This article is a revised version of the presentation at the SIPRI Expert Workshop on Military Expenditure (Stockholm, 28-29 January 2016). I thank the organizers, especially Sam Perlo-Freeman and Noel Kelly. Comments by workshop participants and of this journal' $s$ editors and referees are gratefully acknowledged.

1. Updated and extended SIPRI data: https://www.sipri.org/databases/milex [accessed 16 September 2015]

2. COFOG: http://ec.europa.eu/eurostat/statistics-explained/ index.php/Government_expenditure_by_function_\%E2\%80 $\% 93$ COFOG [accessed 12 June 2016]. Internal and external security functions and institutions in Turkey: See Ayman and Gunluk-Senesen (2016). Turkish national military expenditure data: Gunluk-Senesen (2002, 2010); Gunluk-Senesen and Kirik (2016); Maliye Bakanligi (1993); https://www.muhasebat.gov. tr/content/duyuru/kurulus-bazinda-odenek-ve-harcamalar-tab losu/169150; https://www.muhasebat.gov.tr/content/duyuru/ kurulus-bazinda-odenek-ve-harcamalar-tablosu/155612; http:/www.bumko.gov.tr/TR,4461/butce-gider-gelir-gercekl esmeleri-1924-2012.html [accessed 22 June 2016]. SIPRI methodology: Perlo-Freeman, et al. (2015, pp. 400-402). Estimations for Turkish data with SIPRI methodology since 2006: Yenturk (2014).

3. The Cyprus conflict: Dokos and Tsakonas (2003); Kollias and Gunluk-Senesen (2003); Sonmezoglu and Ayman (2003).

4. DISF: Ayman and Gunluk-Senesen (2016); Gunluk-Senesen (1993); http://www.turksavunmasanayi.gov.tr/en/file/under secretariat-for-defence-industries-stratejic-plan-2012-2016 [accessed 22 June 2016]. A similar, and if possible deeper, comparative data analysis for countries other than Turkey might generate interesting research related to questions of (de)militarization, arming, military burden, and the like. Any such research would likely carry implications for SIPRI- $\alpha$ methodology and data.

5. Arms race literature: For assessments see, e.g., Brauer (2003); Gunluk-Senesen (2004); Kollias, Paleologou and Stergiou (2016). Greek-Turkish relations in the 2000s: Ayman and Gunluk-Senesen (2016); Kollias, Paleologou and Stergiou (2016). SIPRI (2015) does not mention Greece and Turkey among states in conflict.

6 . The correlation coefficient $(r)$ between the SIPRI- $\alpha$ \$2011 and the SIPRI- $\alpha \$ 1990$ series of ratios is unity. The CK\$1990 ratio data is highly correlated with both of these series, $r$ being equal to 0.982 and 0.978 , respectively (see Table 1 ).

7. Chronology of major relations between Greece and Turkey: Gunluk-Senesen (2004), Table 1 and endnote 13 therein.

8. Significance levels of tests: Newbold, Carlson, and Thorne (2003); http://stattrek.com/online-calculator/t-distribution.aspx ; http://stattrek.com/online-calculator/f-distribution.aspx [accessed 3 July 2016]. 
References

Ayman, G. and G. Gunluk-Senesen. 2016. “Turkey’s Changing Security Perceptions and Expenditures in the 2000s: Substitutes or Complements?" Economics of Peace and Security Journal. Vol. 11, No. 1, pp. 35-45. http://dx.doi.org/10.15355/epsj.11.1.35

Brauer, J. 2003. "Turkey and Greece: A Comprehensive Survey of the Defence Economics Literature," pp. 193-241 in C. Kollias and G. Gunluk-Senesen, eds. Greece and Turkey in the 21st Century. The Political Economy Perspective. New York: Nova Science Publishers.

Dokos, T. and P. Tsakonas. 2003. "Greek-Turkish Relations in the Post-Cold War Era," pp. 9-35 in C. Kollias and G. Gunluk-Senesen, eds. Greece and Turkey in the $21^{\text {st }}$ Century. The Political Economy Perspective. New York: Nova Science Publishers.

Gunluk-Senesen, G. 1993. "An Overview of the Arms Industry Modernization Programme in Turkey," pp. 521-532 [Appendix 10E] in SIPRI Yearbook 1993, World Armaments and Disarmament. New York: Oxford University Press.

Gunluk-Senesen, G. 2002. Türkiye'de Savunma Harcamalari ve Ekonomik Etkileri (1980-2001), Istanbul: TESEV.

Gunluk-Senesen, G. 2004. "An Analysis of the Action-Reaction Behaviour in Defense Expenditures of Turkey and Greece." Turkish Studies. Vol. 5, No. 1, pp.78-98. http://dx.doi.org/10.1080/14683849.2004.9687243

Gunluk-Senesen, G. 2010. "Turkey's Defense Expenditures in the 2000s," pp. 143-150 in A. Bayramoglu and A. Insel, eds. Almanac Turkey 2006-2008: Security Sector and Democratic Oversight. Istanbul: TESEV.

Gunluk-Senesen, G. and H. Kirik. 2016. "The AKP Era: Democratization or Resecuritization? An Assessment of the Institutional and Budgetary Reflections." Research and Policy on Turkey. Vol. 1, No. 1, pp. 75-87. http://dx.doi.org/10.1080/23760818.2015.1099783

Kollias, C. 2004. "The Greek-Turkish Rapprochement, the Underlying Military Tension and Greek Defense Spending." Turkish Studies. Vol. 5, No. 1, pp. 99-116. http://dx.doi.org/10.1080/14683849.2004.9687244

Kollias, C. and S.M. Paleologou. 2002. "Is There a Greek-Turkish Arms Race? Some Further Empirical Results from Causality Tests." Defence and Peace Economics. Vol. 13, No. 4, pp. 321-328. http://dx.doi.org/10.1080/10242690212357

Kollias, C. and G. Gunluk-Senesen, eds. 2003. Greece and Turkey in the 21st Century: Conflict or Cooperation? New York: NovaScience.

Kollias, C., S.M. Paleologou and A. Stergiou. 2016. "Military Expenditure in Greece: Security Challenges and Economic Constraints." Economics of Peace and Security Journal. Vol. 11, No. 1, pp. 28-34. http:// dx.doi.org/10.15355/epsj.11.1.28

Maliye Bakanligi.1993. Savunma ve Guvenlik Hizmetleri (1924-1993). Ankara.

Newbold, P., W.L. Carlson, and B. M. Thorne. 2003. Statistics for Business and Economics. London: Prentice Hall.
Perlo-Freeman, S., M. Carriera, A. Fleurant, N. Kelly, P.D. Wezeman, and S. Wezeman. 2015. "Military Expenditure Data, 2005-2014," pp. 373-402 in SIPRI Yearbook 2015: Armaments, Disarmament and International Security. Oxford, UK: Oxford University Press.

[SIPRI] Stockholm International Peace Research Institute. 2015. SIPRI Yearbook 2015: Armaments, Disarmament and International Security. Oxford, UK: Oxford University Press.

Sonmezoglu, F. and G. Ayman. 2003. "The Roots of Conflict and the Dynamics of Change in Turkish-Greek Relations," pp. 37-48 in C. Kollias and G. Gunluk-Senesen, eds. Greece and Turkey in the 21st Century. The Political Economy Perspective. New York: Nova Science Publishers.

Yenturk, N. 2014. "Measuring Turkish Military Expenditure." SIPRI Insights on Peace and Security.http://books.sipri.org/ files/insight/SIPRIInsight1401.pdf [accessed 9 September 2016]. 